Int. J. Dev. Biol. 51: 255-258 (2007)

doi: $10.1387 /$ ijdb.062219ts

Developmental Expression Pattern

\title{
Aard is specifically up-regulated in Sertoli cells during mouse testis differentiation
}

\author{
TERJE SVINGEN, ANNEMIEK BEVERDAM, PALI VERMA, DAGMAR WILHELM and \\ PETER KOOPMAN* \\ Institute for Molecular Bioscience, The University of Queensland, Brisbane, Queensland, Australia
}

\begin{abstract}
Aard (alanine and arginine rich domain) is a gene of unknown function, previously reported to show sexually dimorphic expression in fetal mouse gonads. Here we describe the spatio-temporal expression profile of Aard during gonad development. The period of elevated mRNA expression coincides with early differentiation of the testis and is limited to Sertoli cells of the developing testis cords. Although low levels of Aardtranscripts were detected in other tissues by quantitative RT-PCR assays, high levels of Aard expression is specific to the testis in both embryonic and adult mice.
\end{abstract}

KEY WORDS: Aard, gonad, sex differentiation, testis cord, Sertoli cell

Aard(alanine and arginine rich domain) was initially cloned from and characterized in, postnatal rat lung tissue and named $r A 5 D 3$ (GenBank access. no. NM_145093). Using differential display assays to screen for differentially expressed genes during lung development, Blomberg et al. (2002) found Aardtranscripts to be up-regulated from 2 days post partum (dpp), peaking at $8 \mathrm{dpp}$. Aard was also shown to be expressed in kidney, heart and testis in the early postnatal rat. However, the expression levels in testis were significantly higher than in other tissues in the period between 2 and $14 \mathrm{dpp}$. By combining Northern analyses, library screening and RNase protection assays, Blomberg et al. (2002) further report the potential existence of a three-amino acid truncated isoform of AARD. The function of AARD protein in any tissue is yet to be determined.

The mouse Aardhomologue (GenBank access. no. NM_175503) was first identified as a gene showing sexually dimorphic expression in fetal gonads by PCR-based cDNA subtraction analyses and confirmed to be restricted to the sex cords of $X Y$ gonads by wholemount in situhybridization (Menke and Page, 2002). Male-specific expression of Aard in developing gonads has been confirmed in separate studies (Menke et al., 2003; Bouma et al., 2004; Nef et al., 2005; Beverdam and Koopman, 2006). However the temporal and cell-specific expression profile of Aardin the developing mouse fetus is not yet known. We therefore analysed the expression pattern of Aardin mouse embryos with particular emphasis on gonadal tissues.

Aard expression is significantly up-regulated in the gonads of male fetal mice

Utilising quantitative real-time RT-PCR (qRT-PCR) protocols, Aardexpression was examined in several tissues of 13.5 days post coitum (dpc) mouse embryos (Fig. 1A). Aard transcripts were detectable at low levels in all tissues examined including brain, liver, lung, limb, heart, kidney and ovary. However, in the testis, Aard was significantly up-regulated. These results were confirmed by section in situ hybridization (SISH) on $13.5 \mathrm{dpc}$ male embryos (Fig. 1B). A strong hybridization signal was detected within the testis, with only a weak signal detected in other tissues.

\section{Aard is specifically up-regulated in $X Y$ gonads during seX differentiation}

Further experiments were undertaken to determine whether Aardexpression was up-regulated before or after sex determination. qRT-PCR and whole-mount in situ hybridization (WISH) analyses showed a clear up-regulation of Aardtranscription in XY gonads compared to XX gonads (Fig. 2). By qRT-PCR assays, Aard was detected in the $X Y$ gonads from $11.5 \mathrm{dpc}$, but with a significant increase in mRNA levels thereafter, peaking at around $12.5 \mathrm{dpc}$ (Fig. 2A). WISH experiments confirmed this expression profile, with robust levels of Aardexpression observed from 12.5 $\mathrm{dpc}$, with hybridisation signals limited to the cord structures of the developing testis (Fig. 2B). Sex determination is initiated around $10.5 \mathrm{dpc}$ through the function of the Y-linked gene Sry (Koopman et al., 1990) and testis cords differentiate between 12 and $13.5 \mathrm{dpc}$.

Abbreviations used in this paper: Aard, alanine and arginine rich domain; Dig, digoxigenin; dpc, days post coitum; dpp, days post partum; PBS, phosphatebuffered saline; PFA, paraformaldehyde; qRT-PCR, quantitative real-time; RT-PCR, reverse transcription polymerase chain reaction; SISH, section in situ hybridization; WISH, whole-mount in situ hybridization;

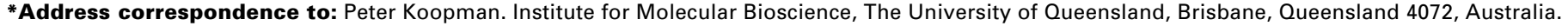
Fax: +61-7-3346-2101. e-mail: p.koopman@imb.uq.edu.au
} 
A

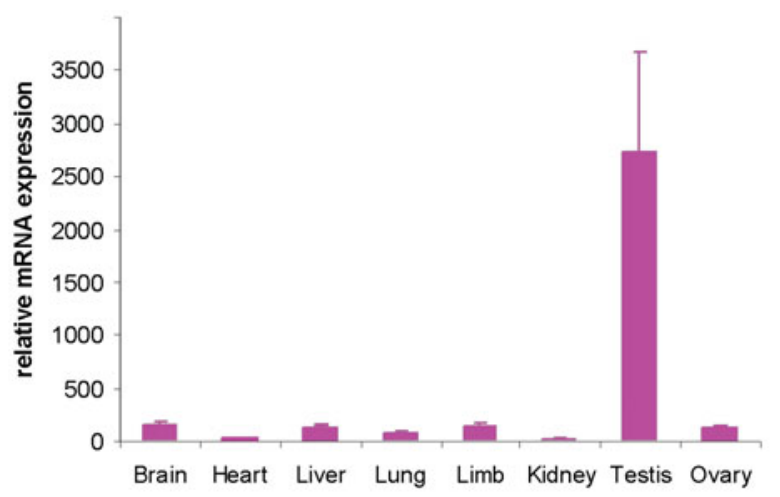

Our data therefore suggest that elevated levels of Aardexpression are associated with the most active phase of testis cord differentiation.

\section{Aard localizes to Sertoli cells in the $X Y$ gonads}

WISH with busulfan-treated fetal gonads and RT-PCR on $W /$ $W^{W}$ gonads has previously shown that Aardexpression persists in germ cell-depleted XY gonads; however these experiments could not exclude the possibility that Aardmight be expressed within the germ cells in addition to somatic cells (Menke and Page, 2002). To clarify this issue, we first repeated WISH and qRT-PCR analyses on $13.5 \mathrm{dpc}$ gonads of $W^{\mathcal{E}} / W^{\mathcal{E}}$ mice (Fig. 3), which are devoid of germ cells (Buehr et al., 1993). As previously shown, Aardtranscripts are detectable by WISH within the cord structures of germ cell-depleted gonads. Further, qRT-PCR data showed persistent Aardexpression in the $W^{e} / W^{e}$ gonads, as did the Sertoli cell marker Sox9, whereas the germ cell marker Oct4 was undetected in the $W^{e} / W^{e}$ gonads. Hence, Aardexpression is not
Fig. 1. Tissue-specific expression of Aard in the mouse embryo. (A) qRT-PCR analysis of Aard $m R N A$ expression relative to $18 \mathrm{~S} R N A$ (Mean \pm SEM of three independent experiments, each performed in triplicate) in several $13.5 \mathrm{dpc}$ mouse embryonic tissues. For each experiment, non-gonadal tissues were pooled from at least three littermate embryos; testes and ovaries were pooled from at least six littermates. The testis expresses Aard at a significantly higher level than other embryonic tissues, including ovary. (B) DIG-labelled sagittal SISH of a 13.5 dpc male embryo. Strong Aard expression is evident within the gonad compared to any other tissue. $M$, midbrain; $F$, forebrain; $S C$, spinal cord; $H$, heart; Lu, lung; Li, liver; G, gonad; K, kidney. Scale bar, $2 \mathrm{~mm}$.

dependent on the presence of germ cells.

To further define the cell type expressing Aard in the testis cords, we performed SISH using gene specific probes for Aard and the cell-specific markers Amh (Sertoli cells) and Oct4 (germ cells). Aard hybridization signal was detected in the Sertoli cells (Fig. $4 \mathrm{~B}, \mathrm{E}$ ), as was $A m h$ (Fig. 4A,D), but not in the germ cells identified by Oct4 hybridization (Fig. 4C,F). Sertoli cells support the germ cells in the differentiated male gonad, with their cytoplasmic processes extending between the germ cells. As shown in Fig. 4, Aardstaining is most prominent in the stellate cytoplasms of the Sertoli cells, but is absent from the annular cytoplasms that characterize the germ cells (compare Fig. 4 E,F). No staining was detected within any other cell types of the testis, including peritubular myoid cells. Hence, Aardexpression localizes to the Sertoli cells in the XY gonad.

Aard expression remains testis-specific in adult mice

Finally, the expression of Aard was examined in adult mouse

A

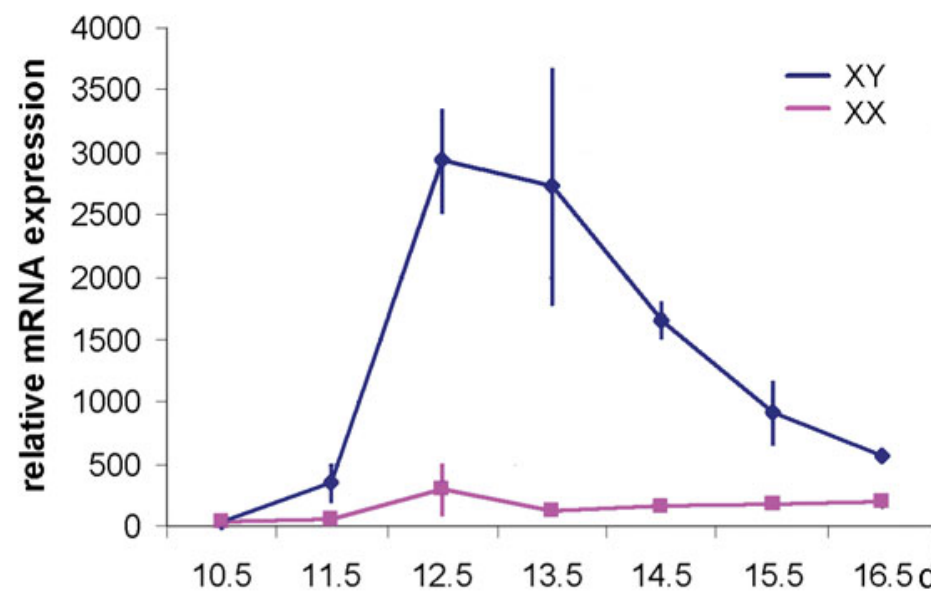

11.5

B

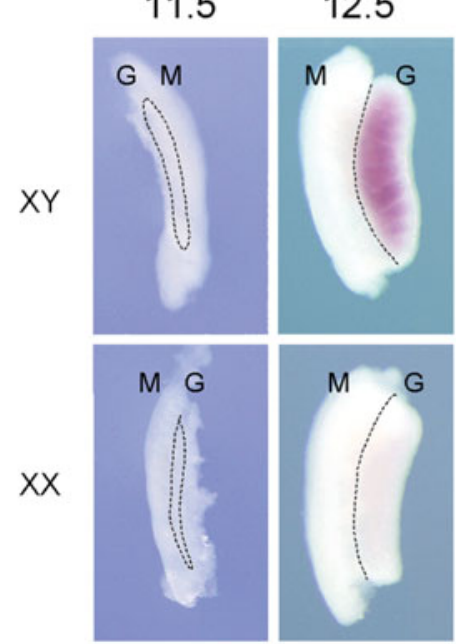

13.5
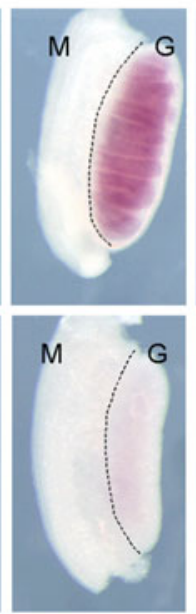

$15.5 \mathrm{dpc}$

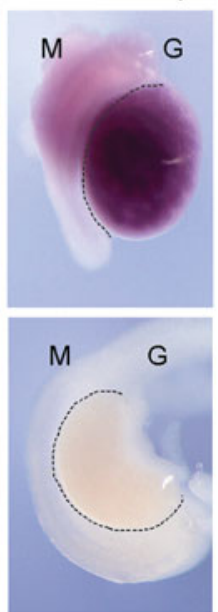

Fig. 2. Temporal expression analysis of Aard in the fetal gonads. (A) qRT-PCR analysis of Aard mRNA expression relative to $18 \mathrm{~S}$ RNA (Mean \pm SEM of three independent experiments, each performed in triplicate) showing male-specific up-regulation in fetal gonads. Individual experiments were performed on RNA obtained from pooled gonads from at least six littermates. Stage $10.5 \mathrm{dpc}$ and $11.5 \mathrm{dpc}$ gonads had mesonephroi attached, whereas later-stage gonadal samples had mesonephroi removed. Aard transcripts are detected in male gonads from $11.5 \mathrm{dpc}$, with transcription levels increasing markedly and peaking at $12.5 \mathrm{dpc}$, after which mRNA levels decreases steadily towards $16.5 \mathrm{dpc}$. (B) WISH analysis confirming malespecific up-regulation of Aard in fetal gonads between 11.5 and $12.5 \mathrm{dpc}$. Apparent strong signal in XY 15.5 dpc gonad is due to sample thickness compared to early-stage gonads. Abbreviations: $M$, mesonephros; $G$, gonad. 
Fig. 3. Germ cell-independent Aard expression in 13.5 dpc testes. (A) $q R T$ $P C R$ analysis of total RNA extracted from $W^{e} W^{e}$ versus pooled wild-type $(+/+)$ and heterozygous (+/We) littermate gonads using gene specific primers for Aard, Sox9 (Sertoli cell marker) and Oct4 (germ cell marker) relative to $18 \mathrm{~S}$ RNA (mean \pm SEM of three

A

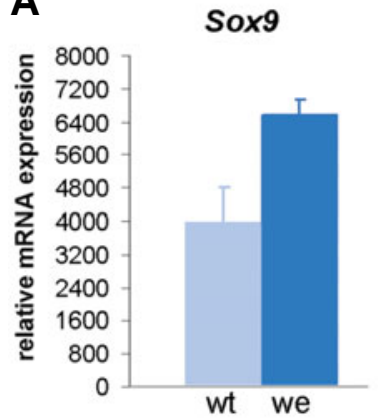

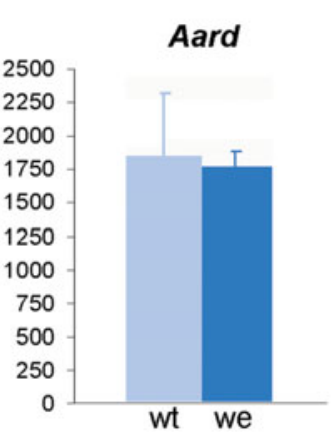

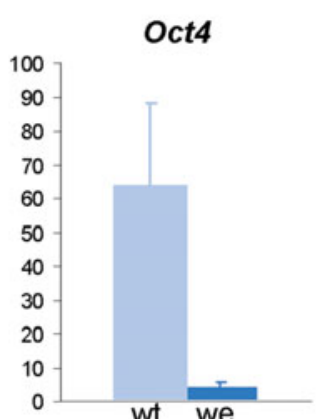

B

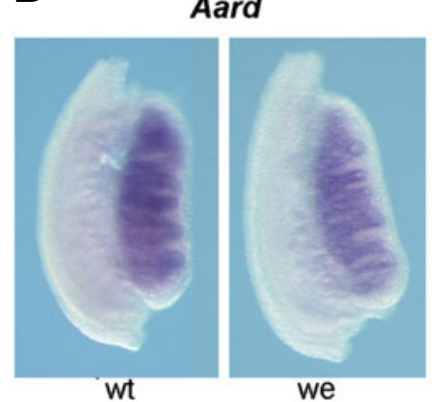
independent experi-

ments). Individual experiments were performed in triplicate on RNA obtained from pooled gonads from 3-4 littermates. Both Aard and Sox9 expression are maintained in germ cell-depleted gonads, whereas Oct4 expression was lost in the We We samples. (B) WISH analysis comparing Aard gene expression in We/We and wild-type (+/+) male gonads. Aard-specific staining is seen in wild-type and littermate We/We gonads. (wt, wild type [+/ + ] and heterozygous [+/We] littermates; we, homozygous We $\mathrm{W}^{\mathrm{e}}$ mutants).

tissues of both sexes. Quantitative analyses showed Aard to be testis-specifically up-regulated in postnatal mice, with only relatively low levels of expression detected in other tissues such as ovary, lung, limb and kidney (Fig. 5). These findings suggest a further role for Aard in postnatal testis function and/or maintenance of testis cell lineages.

In summary, we have shown that Aard is specifically upregulated in testes of the developing mouse embryo relative to ovaries and other tissues. Moreover, AardmRNA is specifically expressed in Sertoli cells of $X Y$ gonads during sex differentiation, with transcription levels peaking around $12.5 \mathrm{dpc}$ when histological differentiation of the testis is most active. Strong testis-specific expression of Aard was also detected in the adult mouse. The presence of a predicted leucine-zipper domain and a phosphorylation site in the AARD protein sequence suggest that AARD may be involved in transcriptional regulation or intracellular signal transduction pathways (Blomberg et al., 2002). Hence, our data suggest that $A A R D$ may be involved in the regulatory hierarchy governing testis cord formation and potentially maintenance of the Sertoli cell lineage in the postnatal testis.

\section{Experimental Procedures}

\section{Animals}

Embryos were collected from timed matings of the CD1 outbred strain and the $\mathrm{C}-\mathrm{Kit}^{\mathrm{We}+/-}$ inbred strain, with noon of the day on which the mating plug was observed designated $0.5 \mathrm{dpc}$. Embryos $11.5 \mathrm{dpc}$ or younger were sexed by Zfy RT-PCR. Primers were Zfy.F: 5'CCTATTGCATGGACTGCAGCTTATG and Zfy.R: 5'GACTAGACATGTCTTAACATCTGTCC. Later-staged embryos were sexed by morphological assessment of gonads.

\section{RNA isolation, cDNA synthesis and SYBR-green qRT-PCR}

Fetal gonads were dissected and pooled according to sex and developmental stage (one litter per pool) then total RNA isolated using the SV Total RNA Isolation System (Promega) according to the manufacturer's instructions. CDNA was synthesised from $1 \mu \mathrm{g}$ total RNA by reverse
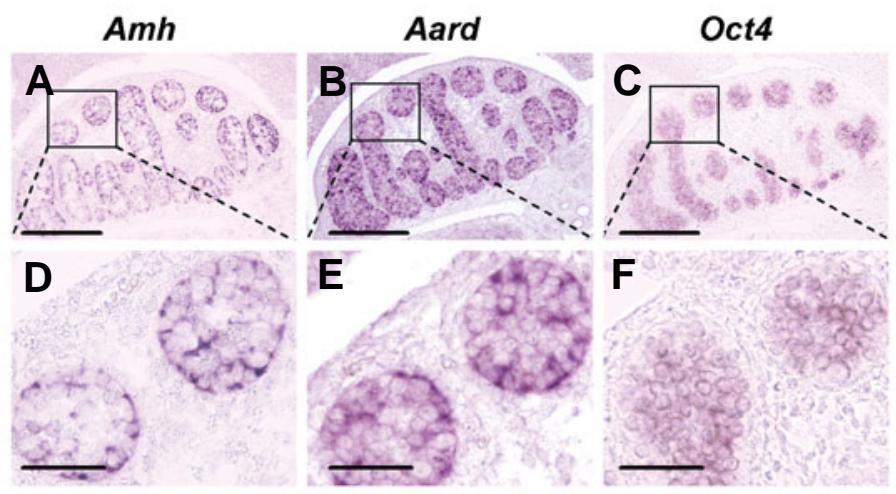

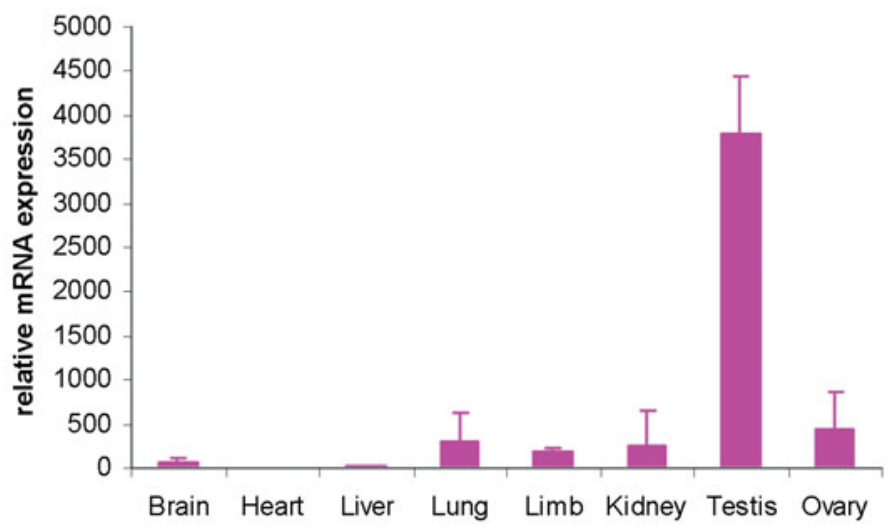

Fig. 4. Cell-specific Aard expression in the fetal male gonad (Left). SISH staining of $13.5 \mathrm{dpc}$ male gonads using specific probes for Amh (A,D), Aard (B,E) and Oct4 (C,F). Aard is expressed in the testis cords and localizes to Sertoli cells. Aard is not expressed in germ cells, with staining different to that observed for the germ cell marker Oct4. Boxed areas indicate regions shown in the square below. Scale bars: $200 \mu \mathrm{m}$ (A, B, C); $100 \mu \mathrm{m}(D, E, F)$.

Fig. 5. Testis-specific expression of Aard in the adult mouse (Right). qRT-PCR analysis of Aard mRNA expression relative to $18 \mathrm{~S}$ RNA (Mean \pm SEM of three independent experiments, each performed in triplicate) in adult mouse tissues. The three independent biological samples were obtained from one male and two female adult mice, with the exception of gonadal tissues, which are represented by three individual ovaries and testes. Aard shows high expression in testis compared to any other tissues examined. 
transcription (Superscript III, Invitrogen) using random primers (Promega) according to manufacturer's instructions (Invitrogen).

qRT-PCR experiments were performed in triplicate and repeated using three different biological samples and comprised of $25 \mu \mathrm{l}$ reactions containing SYBR green PCR master-mix (Applied Biosystems), $3.75 \mu \mathrm{M}$ each forward and reverse primers and $1 \mu \mathrm{l}$ of CDNA, prepared as described using an ABIPrism-7000 Sequence Detector System. PCR was conducted over 40 cycles of $95^{\circ} \mathrm{C}$ for $15 \mathrm{~s}$ and $60^{\circ} \mathrm{C}$ for $1 \mathrm{~min}$ in a twostep thermal cycle, preceded by an initial $10 \mathrm{~min}$ step at $95^{\circ} \mathrm{C}$ to activate the Amplitaq Gold DNA polymerase. Primers used were:

rtAard.F: 5'-GAAGGGAGGAGGGGTGAG and

rtAard.R: 5'-GGCAAACTTTTAGTGCTTTGGT

rtSox9.F: 5'- AGTACCCGCATCTGCACAAC and

rtSox9.R: 5'-TACTTGTAATCGGGGTGGTCT

rtOct4.F: 5'-TGCGGAGGGATGGCATACTG and

rtOct4.R: 5'- GCACAGGGCTCAGAGGAGGTTC. To adjust for variation in input cDNA, samples were normalized against 18SRNA using the $\Delta \mathrm{Ct}$ method. $18 \mathrm{~S}$ primers used were

rt18S.F: 5'-GATCCATTGGAGGGCAAGTCT and

rt18S.R: 5'-CCAAGATCCAACTACGAGCTTTTT. Dissociation curve analyses were performed. The use of 18SRNA as the normalizing gene was further validated by repeating the analyses relative to the housekeeping gene TFIID, which gave the same results as using 185 (Data not shown).

\section{Digoxigenin whole-mount and section in situ hybridization}

Embryos and dissected gonads/mesonephroi were fixed in $4 \%$ paraformaldehyde (PFA) in phosphate buffered saline (PBS) for several hours at $4^{\circ} \mathrm{C}$. WISH with DIG-labelled RNA probes were carried out essentially as described by (Hargrave et al., 2006). For SISH samples, whole embryos were processed and mounted in paraffin wax and stored at $4^{\circ} \mathrm{C}$. SISH was performed on $7 \mu \mathrm{m}$ sagittal sections that were dewaxed, rehydrated and incubated in $5 \mu \mathrm{M} / \mathrm{ml}$ proteinase $K$ for $20 \mathrm{~min}$ at room temperature ( $\mathrm{rt})$, after which samples were washed in PBS. Sections were re-fixed with $4 \%$ PFA for 10 min at rt, acetylated and pre-hybridized with hybridization solution ( $50 \%$ formamide, 5 X SSC, 5 X Denhardts, $250 \mu \mathrm{g} /$ $\mathrm{ml}$ yeast RNA, $500 \mu \mathrm{g} / \mathrm{ml}$ herring sperm DNA) for $2 \mathrm{~h}$ at rt. Hybridization $(0.5 \mu \mathrm{g} / \mathrm{ml}$ probe in hybridization solution) was performed overnight at $60^{\circ} \mathrm{C}$. Slides were washed in $5 X \mathrm{SSC}$ for $5 \mathrm{~min}, 0.2 \mathrm{XSSC}$ for $1 \mathrm{~h}$ at $60^{\circ} \mathrm{C}$, $0.2 \mathrm{XSC}$ for $5 \mathrm{~min}$ at $\mathrm{rt}$ and NT buffer $(150 \mathrm{mM} \mathrm{NaCl}, 50 \mathrm{mM}$ Tris- $\mathrm{HCl}$ $\mathrm{pH} 7.5)$ for $5 \mathrm{~min}$ at $\mathrm{rt}$, before blocking for $2 \mathrm{~h}$ with blocking solution (10\% heat-inactivated sheep serum in NT buffer) in a humidified chamber. AntiDIG antibody (Roche) in blocking solution (1:2000) was added to the slides and incubated overnight at $4^{\circ} \mathrm{C}$. Unbound antibodies were removed by washing three times in NT buffer. Section were equilibrated in NTM buffer $(100 \mathrm{mM} \mathrm{NaCl}, 100 \mathrm{mM}$ Tris- $\mathrm{HCl} \mathrm{pH} \mathrm{9.5,} 50 \mathrm{mM} \mathrm{MgCl})$ and incubated in colour solution (3.5 $\mu \mathrm{l} \mathrm{BCIP} \mathrm{(Roche),} 3.5 \mu \mathrm{INBT}$ (Roche) per $\mathrm{ml}$ NTM buffer) until purple staining was satisfactory.

A 233 bp Aardfragment was cloned from position 638-871 (GenBank access. no. NM_175503) into pGEM T-Easy vector (Promega) and targets the 3' UTR, thus detecting both isoforms reported by Blomberg et al. (2002). Primers used were Aard.F: 5'-GCTCTGAAACCCTCCTACC and Aard.R: 5'-TGCTTTGGTTGTCTTCCACC. The probes for Amh and Oct4 were made as previously described (Münsterberg and LovellBadge, 1991; Schepers et al., 2003).

\section{Acknowledgements}

PK is a Professorial Research Fellow of the Australian Research Council (ARC) and acknowledges grant support from the $A R C$ and the National Health and Medical Research Council of Australia.

\section{References}

BEVERDAM, A. and KOOPMAN, P. (2006) Expression profiling of purified mouse gonadal somatic cells during the critical time window of sex determination reveals novel candidate genes for human sexual dysgenesis syndromes. Hum Mol. Genet. 15: 417-431.

BLOMBERG, L.A., CHAN, W.Y., CLERCH, L.B. and MASSARO, D. (2002) Molecular cloning and characterization of a novel gene upregulated early during postnatal rat lung development. Biochim. Biophys. Acta. 1574: 391-398.

BOUMA, G.J., HART, G.T., WASHBURN, L.L., RECKNAGEL, A.K. and EICHER, E.M. (2004) Using real-time RT-PCR analysis to determine multiple gene expression patterns during $\mathrm{XX}$ and $\mathrm{XY}$ mouse fetal gonad development. Gene Expr. Patterns 5: 141-149.

BUEHR, M., MCLAREN, A., BARTLEY, A. and DARLING, S. (1993) Proliferation and migration of primordial germ cells in We/We mouse embryos. Dev. Dyn. 198: 182-189.

HARGRAVE, M., BOWLES, J. and KOOPMAN, P. (2006) In situ hybridization of whole mount embryos. Methods Mol. Biol. 326: 103-113.

KOOPMAN, P., MÜNSTERBERG, A., CAPEL, B., VIVIAN, N. and LOVELLBADGE, R. (1990) Expression of a candidate sex-determining gene during mouse testis differentiation. Nature 348: 450-452.

MENKE, D.B., KOUBOVA, J. and PAGE, D.C. (2003) Sexual differentiation of germ cells in XX mouse gonads occurs in an anterior-to-posterior wave. Dev. Biol. 262: 303-312.

MENKE, D.B. and PAGE, D.C. (2002) Sexually dimorphic gene expression in the developing mouse gonad. Gene Expr. Patterns 2: 359-367.

MÜNSTERBERG, A. and LOVELL-BADGE, R. (1991) Expression of the antiMüllerian hormone gene suggests a role in both male and female sexual differentiation. Development 113; 613-624.

NEF, S., SCHAAD, O., STALLINGS, N.R., CEDERROTH, C.R., PITETTI, J.-L., SCHAER, G., MALKI, S., DUBOIS-DAUPHIN, M., BOIZET-BONHOURE, B., DESCOMBES, P., PARKER, K.L. and VASSALLI, J.-D. (2005) Gene expression during sex determination reveals a robust female genetic program at the onset of ovarian development. Dev. Biol. 287: 361-377.

SCHEPERS, G., WILSON, M., WILHELM, D. and KOOPMAN, P. (2003) SOX8 is expressed during testis differentiation in mice and synergizes with SF1 to activate the Amh promoter in vitro. J. Biol. Chem. 278: 28101-28108.

Received: 12th September 2006 Reviewed by Referees: 3rd October 2006

Modified by Authors and Accepted for Publication: 27th November 2006 Published Online: 27th April 2007

\section{Previously published related Int. J. Dev. Biol. articles}

See our recent Special Issue on Mammalian Reproduction and Development edited by B. Hogan at:

http://www.ijdb.ehu.es/web/contents.php?vol=45\&issue=3

P450 aromatase expression in the temperature-sensitive sexual differentiation of salamander (Hynobius retardatus) gonads Natsuko Sakata, Yoichiro Tamori And Masami Wakahara

Int. J. Dev. Biol. (2005) 49: 417-425

Effects of FGF9 on embryonic Sertoli cell proliferation and testicular cord formation in the mouse

Louise Willerton, Robert A. Smith, David Russell and Sarah Mackay

Int. J. Dev. Biol. (2004) 48: 637-643 